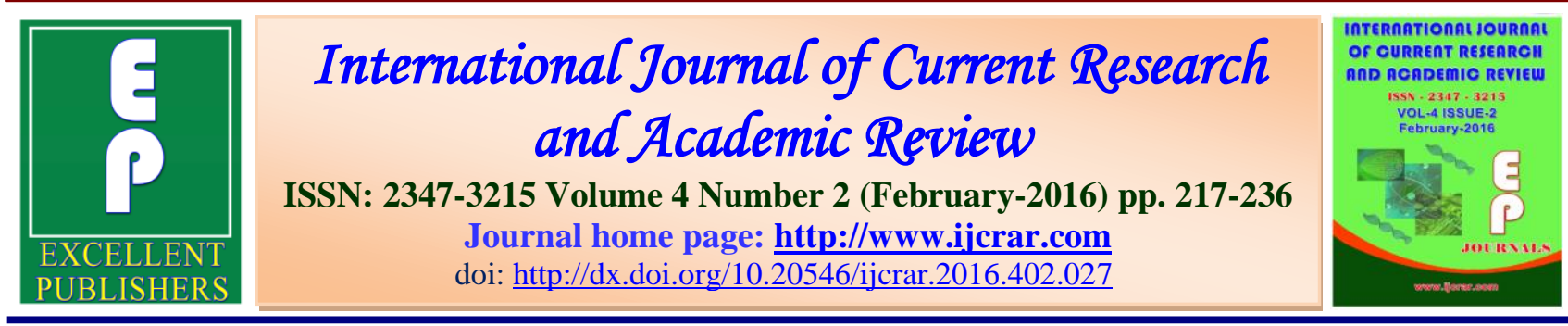

\title{
Predictive validity of Mock senior School certificate examination on external wassce scores in agricultural science in Abia state, Nigeria
}

\author{
Madu, Aldophus ${ }^{1 *}$ and Ebere, Collins ${ }^{2}$
}

${ }^{1}$ Department of Science Education, Michael Okpara University of Agriculture, Umudike, Abia State, Nigeria

${ }^{2}$ Department of Agricultural/Home Economics Education, Michael Okpara University of Agriculture, Umudike, Abia State, Nigeria

*Corresponding author

\section{KEYWORDS}

Predictive Validity, Mock Senior School Certificate

Examination, WASSCE Scores in Agricultural Science

\section{A B S T R A C T}

The study was carried out to investigate the predictive validity of students' scores in Mock Senior School Certificate Examination on their scores in WASSCE in Agricultural Science between 2010/2011-2013/2014 academic sessions in Umuahia Education Zone of Abia State. The study was guided by five research questions and five hypotheses. The study adopted the Descriptive Survey Design which comprised correlational and ex-post facto research design. The population of the study was 7213 which comprised 3896 male students and 3317 female students, while 3627 were students from rural schools and 3586 were from schools in urban areas. The study used a total of forty eight(48) public secondary schools from four(4) Local Government Areas. The study adopted the multi-stage sampling to select twenty three (23) secondary schools. The sample was made up of 3907 students which comprised 2050 male students and 1857 female students, 1641 students from schools in rural areas and 2266 students were from schools in urban areas who sat for the Mock Senior School Certificate Examination and WASSCE Agricultural Science between 2010/2011-2013/2014 academic sessions. The students were purposively sampled while the proportionate stratified random sampling technique was used to select schools from the four (4) Local Government Areas. The data for the study was collected using the Proforma where the researcher copied the students' scores in Mock SSCE and SSCE conducted by the West African Examination Council(WAEC)

The research questions were analysed using the Spearman Rank Order Correlation Coefficient Statistic while the hypotheses were analysed using Simple Linear Regression. The findings revealed that there was a moderate positive correlation which was significant between the students Mock Senior School Examination scores and their Scores in Senior School Certificate Examinations in Agricultural Science conducted by West African Examination Council (WAEC) with $\mathrm{r}$ values of 0.696 at $\mathrm{P}<0.05$. It was also revealed that the students Mock Senior School Certificate Examination scores significantly predicted their Scores in Senior School Certificate Examinations scores in Agricultural Science conducted by West African Examination Council (WAEC) with $\mathrm{R}=0.651$ and prediction equation of WASSCE $=1.642+0.706$ Mock examination. Based on the findings, the study recommended that since the Mock Senior School Certificate Examination is very useful in predicting student's scores in SSCE, any student who fails the Mock Senior School Certificate Examination should be placed on remedial activities before registering or sitting for WASSCE to avoid failure and Mock Senior School Certificate examination should be continued as a way for preparing students in the WASSCE. 


\section{Introduction}

In the Nigerian educational system, achievement at any level is crowned with certification for those who successfully complete the course of study. This certification can be achieved by the administration of end of year examinations which are summative evaluations. These summative evaluations are usually in the form of examinations, Ukwuije (2012) defined examination as a measure of sample of behaviour, which is used for Certification. There are two major forms of examination taken in Nigeria and they are classified according to bodies which conduct the examination and these are internal and external examinations.

The internal examinations are conducted by various schools which include the Mock both at the Junior Secondary and Senior Secondary Schools while the external examinations are conducted by external examination bodies which include the West African Examination Council (WAEC) which conducts the West African Senior Secondary School Certificate Examination (WASSCE), National Examination Council (NECO) which conducts both the Senior Secondary School Certificate Examination and the Basic Education Certificate Examination(BECE) for all Unity schools in Nigeria. The National Business and Technical Examination Board(NABTEB), which also conducts External Senior School Certificate Examination for both business, secretariat and technical schools. The Joint Admissions and Matriculations Board (JAMB) conducts the Unified Tertiary and Matriculations Examination (Ukwuije 2012).

For the purpose of this study, Mock-Senior School Certificate Examination is seen as internal examination and public examinations are viewed as external School examinations open to the public and conducted by the external examination bodies using tests that have appropriate psychometric properties. According to Adeyegbe (2004), these tests used by various public examinations board are often better developed than the one prepared by the teachers in the school setting. Examinations, both internal such as Mock and external such as West African Senior Secondary Certificate Examination, National Examination Council Senior Secondary Certificate Examinations are used for grading and placement in the education system. This is to ensure that goals of secondary education that are spelt out in the National Policy on Education are achieved. The National Policy on Education (FRN, 2013) stipulates that secondary education has among others the following goals:

i. to provide all primary school leavers with the opportunity for education of a higher level, irrespective of sex, social status, religious or ethnic background.

ii. to provide trained manpower in the applied science, technology and commerce at sub-professional grades,

iii. to inspire students with a desire for self improvement and achievement for excellence

iv. to raise generation of people who can think for themselves, respect the views and feelings of others, respect the dignity of labour, appreciate those values specified under our broad National goals and live as good citizens.

From the fore going, Secondary education is very imperative and plays a prominent role towards National development and manpower training. According to the 9-3-4 system of education that is operational in 
Nigeria, the Senior Secondary Education takes three years. The Senior Secondary School runs for a period of three academic sessions. At the Senior Secondary School level, many subjects are offered; they include the arts, vocational, social sciences, commercial sciences (Nlebem, 2011). Agricultural science is one of the elective science subjects which students from arts, vocational and commercial can select.

Agricultural science can be defined as the science of rearing of animals and raising of crops for human consumption (Erebor, 2003). The subject is a very important subject in our society and our educational system, because of the growing influence of Agriculture in the economy of Nigeria especially in the presence of dwindling oil prices. Agriculture is the mainstay in any Nation's economic and social development (Joshua, 2007), It contributes to about 68\% of the labour force in Nigeria, as it is also the principal sources of livelihood in Nigeria. In spite of the vast arable land, conducive climate and different agricultural programmes, the hope of Nigeria attaining self sufficiency in food production has not been realized (FAO,2006). Due to the importance of Agriculture to the Nigerian economy, it remains one of the few subjects that is offered at Primary, Junior Secondary, Senior Secondary Schools and Tertiary institution. Agricultural science is classified as a vocational subject in the National Policy on Education (FRN, 2004). A good knowledge of Agricultural science is a pre requisite for the study of Agriculture and its allied Courses such as Agricultural Economics, Animal Science, Crop Science and Production. This importance gave rise to the objectives of Agricultural Science as stipulated in the Agricultural Science Curriculum to include, stimulating and sustaining student's interest in Agriculture, enabling students to acquire basic knowledge and practical skills, preparing students for future occupations.

In other to achieve best performance in Agricultural Science at WASSCE, adequate preparations are given to the students prior to WASSCE. Some of these preparations include intensive coaching for the students, and sitting for the Mock Senior School Examination. According to Okoye (2006), Mock-Senior School Certificate Examination is a pre-requisite examination which prepares candidates for the final Senior School Certificate Examination. According to Nlebem (2011), the Senior School Certificate Examination is an external examination while the internal examination set after the pattern of the Senior School Certificate Examination is called the Mock Senior School Examination. The Mock Senior School Certificate Examination is therefore an examination that makes mockery of the WASSCE or made to look exactly in content and cognitive requirements as the Senior School Certificate Examination (Emmanuel et al.,,2011). The performance of students in Mock Senior School Certificate Examination is an important indicator or factor that may relate to overall performance of students in WASSCE. The performance of students in the WASSCE has not been encouraging. For example in Nigeria, in $200946.6 \%$ of the total number of students who entered for Agricultural Science at West African Senior Secondary School Certificate Examination made A1-C6. In $2010,47.3 \%$ of the total number of students who entered for Agricultural Science at West African Senior Secondary School Certificate Examination made A1-C6. In $2011,52.60 \%$ of the total number of students who entered for Agricultural Science at West African Senior Secondary School Certificate Examination made A1C6. In 2012, $52.44 \%$ of the total number of 
students who entered for Agricultural Science at West African Senior Secondary School Certificate Examination made A1C6. In 2013, 73.09\% of the total number of students who entered for Agricultural Science at West African Senior Secondary School Certificate Examination made A1C6. In 2014, $61.60 \%$ of the total number of students who entered for Agricultural Science at West African Senior Secondary School Certificate Examination made A1-C6 (Olorundare, 2014). In Abia State, $43.7 \%$ of the total number of students who entered for Agricultural Science at West African Senior Secondary School Certificate Examination made A1-C6 in 2011. In 2012, 49.8\% made AI-C6 in WASSCE, there was a significant improvement in 2012. In Abia State in 2013, $68 \%$ of the students made A1-C6 in West African Senior Secondary School Certificate Examination (WASSCE). In 2014, there was a slight decrease in the academic performance as $62.6 \%$ made A1-C6 in West African Senior School Certificate Examination (Abia State SEMB, 2014).

According to Nkemakolam (2009) validity is referred to as the extent to which an instrument or a test measures what it is intended to measure or what it purports to measure, while Olatunji et al.(2004) defined predictive validity as the extent to which the result of a test is able to forecast performance in other related activities occurring later on. Previous studies have questioned the validity and predictive validity of teacher made test such as Mock Senior School Examination. It is believed that teacher made tests have poor or lack proper psychometric properties such as the difficulty, discrimination, distractor effectiveness, reliability and validity. Ukwuije (2012) asserted that teacher made tests do not possesses good psychometric properties. On the other hand the Mock Senior School Certificate Examination is usually conducted to prepare students for the WASSCE. Since these tests are said to be poor in psychometric properties, can we ascertain whether Mock-Senior School Certificate Examination scores significantly predict the WASSCE scores in Agricultural Science? To what extent do variables like school type, gender and school location influence predictive validity of Agricultural Science Mock-Senior School Certificate Examination scores on Senior School Certificate Examination? Can we say that those who perform well in Mock-Senior Secondary Certificate Examination could equally do well in the Senior School Certificate Examination? The outcome of this study will help to encourage intensifying efforts in preparing students using the Mock-Senior School Certificate Examination or suggest possible ways of achieving this.

Furthermore, to adopt a wholistic approach in finding the predictive validity of students' scores in Mock Senior School Certificate Examination on WASSCE in Agricultural Science, it will be necessary to examine those factors which influence the performances of students in Agricultural Science. These factors include gender and school location. Studies by Salau (1999) based on gender revealed that male perform better than female in Science Subjects. Similarly, Adesoji and Kenni(2013) found out that both male and female student's performance in Mock Senior School Certificate Examination predicted their performance in West African Senior School Certificate Examination in Chemistry. The study of Nlebem (2011) revealed that there was a significant relationship between Mock Senior School Certificate Examination scores and the External Senior School Certificate Examination scores of female and male students, this she attributed to the fact that females now compete with the male 
Int.J.Curr.Res.Aca.Rev.2016; 4(2): 217-236

students in various aspect of life. The study of Nlebem (2011) revealed that there was a significant relationship between student's scores in Mock Senior School Certificate Examination and External Senior School Certificate Examination Biology in both urban and rural schools. In the midst of these inconsistencies of results, the present study will seek to find the Predictive Validity of Mock Senior School Examination Scores on Senior School Certificate Examination Scores in Agricultural Science based on gender of students and school location of students

Recently students are faced with the problem of writing many examinations, which include the internal and external examinations such as the Senior School Certificate Examination, Unified Tertiary and Matriculation Examination and PostUnified Tertiary and Matriculation Examination in various universities. There is the need to solve the problem of writing multiple examinations. The Senior School Certificate Examination is an achievement test used for certifying students and they guarantee student admission into higher institution, including securing job opportunities. In most cases, fears have been raised on the authenticity of the WASSCE because of alleged examination malpractices and the influence of factors such as gender and school location. It is then necessary for an effective model be evolved for conducting periodic checks on the predictive validity of the Mock Senior School Certificate Examination. In this regard one may ask is the Mock-Senior School Certificate Examination scores a good predictor of the External Senior School Certificate Examination scores.

\section{Purpose of the Study}

The purpose of this study is to determine the predictive validity of students' scores in
Mock Senior School Certificate Examination on External Senior School Certificate Examination Scores in Agricultural Science. It has the following specific objectives; To

i. find out the correlationship between students Mock Senior School Certificate Examination scores and their WASSCE scores in Agricultural Science.

ii. find out the correlationship between male students Mock Senior School Certificate Examination scores and their WASSCE scores in Agricultural Science.

iii. establish the correlationship between female students Mock Senior School Certificate Examination scores and WASSCE scores in Agricultural Science.

iv. establish the correlationship between the Mock Senior School Certificate Examination scores of students in schools located in Rural area and their WASSCE scores in Agricultural Science.

v. establish the correlationship between the Mock Senior School Certificate Examination scores of students in schools located in Urban area and their WASSCE scores in Agricultural Science.

vi. determine whether the students Mock Senior School Certificate Examination scores predict their WASSCE scores in Agricultural Science.

vii. determine whether the female students Mock Senior School Certificate Examination scores predict their External Senior School Certificate 
Int.J.Curr.Res.Aca.Rev.2016; 4(2): 217-236

Examination scores in Agricultural Science.

viii. determine whether the male students Mock Senior School Certificate Examination scores predict their WASSCE scores in Agricultural Science.

ix. determine whether the Mock Senior School Certificate Examination Scores of students in schools located in Rural areas predict their WASSCE scores in Agricultural Science.

x. determine whether the Mock Senior School Certificate Examination Scores of students in schools located in Urban areas predict their WASSCE scores in Agricultural Science.

\section{Research Methodology}

\section{Research Design}

The Descriptive Survey Research Design which comprised Correlational and Expostfacto studies design was employed for this study. The Descriptive Survey Research Design is one directed towards determining the nature of situation as it exists at the time of the study, (Maduabum, 2004). This was because data was collected from a relatively large number of people considered to be a representative of the entire group. It comprised Correlational and Expost- facto studies design. The Correlational and Expost- facto studies design were employed to investigate the relationship that exist between the performance of students in Mock-Senior School Certificate Examination (predictor variables) and West African Senior School Certificate Examinations (Criterion Variable) between 2010/2011 - 2013/2014 academic sessions. Correlational studies design are defined as studies design which are aimed at determining the relationship between two or more variables and enabling us to ascertain the extent to which variation in one variable are associated with variations in another (Maduabum,2004). The Correlational Studies design was used in this study because the researcher is interested in finding the relationship that exists between the Mock-Senior School Certificate Examination and the WAEC Senior School Certificate Examination. The latter design which is the Expost facto was used because both the cause and the effect had already occurred while the data involved in the study were as they were, when collected from their sources without any manipulation (Maduabum,2004,). This design was adopted because the results of Mock-Senior School Certificate Examination and the WAEC already existed.

\section{Area of Study}

This study was conducted in Umuahia Education Zone of Abia State. Umuahia education zone comprised Secondary Schools in four Local Government Areas (L.G.A) namely, Umuahia North, Umuahia South, Ikwuano and Umunneochi. Umuahia Education Zone is bounded to the North by Anambra and Enugu State, bounded to the south by Isiala Ngwa North, to the East by Akwa-Ibom State and to the West by Imo State. The occupation of the people of Umuahia Education Zone are mainly farming and trading. The researchers choose the study in this zone because of his familiarity of the zone. It is also a zone that is exploring all avenues to improve students 'performance in External Senior School Certificate Examination especially in Agricultural Science. It is also an agrarian zone in Abia State and wants to promote students interest in Agriculture. 


\section{Population of Study}

The accessible population of schools consisted of all the Senior Secondary School Three (3) students who sat for the External Senior School Certificate Examination conducted by the West African Examination Council between 2010/2011- 2013/2014 academic sessions respectively in Umuahia Zone of Abia State, as provided by the Abia State Ministry of Education (2014).

There are a total of seven thousand two hundred and thirteen students (7213) which comprise 3896 male students and 3317 female students, 3627 from schools in rural areas and 3586 from schools in urban areas from a total of forty eight (48) Public Senior Secondary Schools which comprised of nine (9) schools located in urban areas and thirty nine (39) schools located in rural areas that have sat for the Senior School Certificate Examination conducted by West African Examination Council (WAEC) between 2010/2011-2013/2014 academic session respectively in Umuahia Education Zone of Abia state. The forty eight (48) schools constitute the target population, because they have attained Senior Secondary School III, offer Agricultural Science as a subject and have sat for the Senior School Certificate Examination conducted by both West African Examination Council (WAEC) in the years under study

\section{Sample and Sampling Techniques}

The sample of Students consisted of 3907 which comprised 2050 male Students and 1857 female students, 1641 from schools in rural location and 2266 from schools in urban location who sat for the Mock-Senior School Certificate Examination, West African Senior School Certificate Examination between 2010/20112013/2014 academic sessions from a total of twenty three (23) schools selected for the study. The sampled students represent 54\% of the population of students for the study. This was considered adequate, because Nwanna (2007) recommended even the use of $10 \%$ for a population of few thousand. (See appendix 4 for the distribution of sampled Students according to gender and schools location across the four Local Government Areas.

The multi stage sampling techniques was adopted for the study. The first stage involves the selection of Urban schools using the purposive sampling technique because they are few in numbers while the proportionate stratified sampling was used to select the Rural schools across the four Local Government Area. The Purposive sampling was used to sample the students from the schools that make up the sample schools. The sample schools comprised twenty three (23) schools in Umuahia Education zone of Abia State, which represents $48 \%$ of the school population. This was considered adequate, because Nwanna (2007) recommended even the use of $10 \%$ for a population of few thousand. The selected schools comprised of nine (9) schools from Urban Areas and fourteen (14) from Rural schools. (see Appendix 7 for the list of selected schools for the main study). The Urban schools were selected using the purposive sampling technique because they are few in numbers while the proportionate stratified sampling was used to select the Rural schools across the four Local Government Area.

This involves the listing of all the schools in Rural areas in each of the four Local Government Areas and selecting them based on proportionate stratified simple random sampling. First and foremost a sampling fraction for the selection of the number of schools in Rural areas according to the 
Local Government Areas was determined as follows.

$\mathrm{S} . \mathrm{F}=\frac{n}{N}$

Where SF = sampling fraction

$\mathrm{n}=$ sample size of schools

$\mathrm{N}=$ total number of schools in the four Local Government Areas

Therefore Sampling Fraction used for selecting the school located in the Rural areas in each of the local Government Area was $\frac{14}{39}=0.36$

0.36 was used to multiply all schools located in Rural areas according to Local Government Area. This was followed by listing the schools in each Local Government Area and their serial number recorded in piece of papers. The piece of papers were folded and placed in a hat and mixed thoroughly. Simple random sampling was conducted by asking one of the research assistants to pick a piece of paper at a time up to the required number of schools. The schools bearing the serial numbers picked formed the sample schools located in Rural Areas which was used for this study. (see Appendix 7 for sampled schools located in Rural areas)

\section{Instrument for Data Collection}

The instrument for data collection was collected using a Proforma which enabled the researcher copy the students' scores in Mock-Senior School Certificate Examination and the External Senior School Certificate Examination conducted by West African Examination Council in Agricultural Science. The results were collected in the form of ordinal data. Both the Mock-Senior School Certificate Examination and External Senior School Certificate Examination conducted by WAEC were graded using the revised stanine scores of
$\mathrm{A}_{1}$ Excellent
$\mathrm{B}_{2} \quad$ Very Good
$\mathrm{B}_{3}$ Good
$\mathrm{C}_{4} \quad$ Credit
$\mathrm{C}_{5} \quad$ Credit
$\mathrm{C}_{6} \quad$ Credit
$\mathrm{D}_{7} \quad$ Pass
$\mathrm{E}_{8} \quad$ Pass
$\mathrm{F}_{9} \quad$ Fail.

\section{Data Collection Procedure}

The Mock-Senior School Certificate Examination, West African Senior School Certificate Examination results were sourced from the examination record units of the various schools sampled using a Proforma, hence the study made use of primary data.

\section{Method of Data Analysis}

The research questions 1, 2,3,4 and 5 was answered using the Spearman Rank Order Correlation Coefficient statistic to determine the extent of relationship between the Mock-Senior School Certificate Examination and External Senior School Certificate Examination conducted by West African Examination Council. The relationship between Mock-Senior School Certificate examination and WASSCE was answered separately using West African Senior School Certificate Examination and scores in Agricultural Science separately. The Spearman Rank Order Correlation 
Coefficient Statistic was used because the scores for the Mock-Senior School Certificate Examination and External Senior School Certificate Examination were collected in an ordinal form.

\section{Results and Discussion}

The Spearman Rank Order Correlation Coefficient between the scores in MockSenior School Certificate Examination and their scores in West African Senior School Certificate Examination between 2010/2011-2013/2014 academic sessions shows a moderate positive correlation with an $r$ value of 0.696 which is significant ( $p<$ 0.05 ) at 0.01 level of significance.

The Spearman Rank Order Correlation Coefficient between the male students scores in Mock Senior School Certificate Examination and the West African Senior School Certificate Examination(WASSCE) scores in Agricultural Science shows a very highly positive correlation with an r-value of 0.971 which is significant $(\mathrm{p}<0.05)$ at 0.01 level of significance.

The Spearman Rank Order Correlation Coefficient between the female students scores in Mock Senior School Certificate Examination and their scores in West African Senior School Certificate Examination(WASSCE) scores in Agricultural science shows a very high positive correlation with an r-value of 0.991 which is significant $(\mathrm{p}<0.01)$ at 0.01 level of significance.

The Spearman Rank Order Correlation Coefficient between the students' scores in Mock Senior School Certificate Examination of schools located in Rural areas and their scores in West African Senior School Certificate Examination (WASSCE) shows a high positive correlation with an r-value of 0.792 which is significant $(p<0.05)$ at 0.01 level of significance.

The Spearman Rank Order Correlation Coefficient between the students' scores in the Mock Senior School Certificate Examination of Schools located in Urban Areas and their scores in West African Senior School Certificate Examination (WASSCE) Agricultural science shows a moderate positive correlation with an $r-$ value of .640 which is significant $(\mathrm{p}<0.05$. $)$ at 0.01 level of significance.

Data in the table 6 reveals that with an $R$ value of 0.651 , it implies that there is a moderate positive Pearson's Product Moment Correlation Coefficient between the Mock Senior School Certificate Examination scores and their West African Senior School Certificate Examination (WASSCE) scores in Agricultural Science. The R.square which is the Coefficient of Determination is 0.424; therefore about $42.4 \%$ of the variation of scores in West African Senior School Certificate Examination (WASSCE) is explained by the scores in Mock Senior School Certificate Examination. The regression equation appears to be useful for making prediction since the $r^{2}$ of 0.424 is positive.

Data in table 7 show that an F- value of 2875.071 and $p$ - value of 0.000 since the $p-$ value $=0.000$, at $\mathrm{p}<0.05$, we shall reject the null hypothesis which states that student scores in Mock Senior School Certificate Examination in Agricultural Science do not significantly predict their scores in WASSCE Agricultural science between 2010/2011 - 2013/2014 academic sessions. Hence we accept the alternate hypothesis which is, the students' scores in Mock Senior School Certificate Examination Agricultural Science significantly predicts their scores in WASSCE Agricultural 
Int.J.Curr.Res.Aca.Rev.2016; 4(2): 217-236

science between 2010/2011 - 2013/2014 academic sessions.

Data in table 8 establishes the prediction equation, as the unstandardized coefficient values of B are 1.642 and 0.706 for the slope and intercept respectively, therefore the prediction equation is $\mathrm{WAEC}=1.642+$ $0.706 \mathrm{MOCK}$. It was also revealed that at 0.05 level of significance with a p-value of 0.000 , which is less than 0.05 , it implies that the students' scores in MOCK SSCE Agricultural Science significantly predict scores in WASSCE Agricultural science between $2010-2011-2013 / 2014$ academic sessions.

Data in table 9 shows an $\mathrm{R}$ value of 0.989 which implies that there is almost a perfect Pearsons Products Moment Correlation Coefficient between the female students in Mock Senior School Certificate Examination and their scores in WASSCE between 2010/ 2011-2013/2014 academic sessions. It also shows an $\mathrm{R}$ square of 0.978 which is the Coefficient of Determination. This implies that $97.8 \%$ of the WASSCE Agricultural science is explained or accounted for by the Mock Senior School Certificate Examination. The shows that the regression equation for the female scores appear to be very useful for making prediction since the $R^{2}$ value of 0.978 is close to 1 .

Data in table 10: Shows an F-value of 83557.405 and $p$-value of 0.000 , since the $p$ value of 0.000 is less than 0.05 , we shall reject the null hypothesis which states that students' scores in Mock Senior School Certificate Examination Agricultural science do not significantly predict their scores in WASSCE Agricultural science between 2010/2011-2013/2014 academic sessions. Therefore we accept the alternate hypothesis which implies that female students scores in
Mock Senior School Certificate Examination significantly predicts their scores in WASSCE Agricultural science between 2010/2011-2013/2014 academic sessions.

Regression or Prediction Equation WASSCE $=0.048+0.982$ Mock Examination.

Data in Table 11 establish the prediction or regression equation as the unstandardized coefficient values of B are 0.048 and 0.982 for the slope and the intercept respectively. Therefore the prediction equation for female scores is WASSCE $=0.048+0.982$ Mock Examination. It also reveals that at 0.05 level of significance with a p-value of 0.000 which is less than 0.05, this implies that female student scores in Mock Senior School Certificate Examination Agricultural science significantly predicts scores in WASSCE Agricultural science between 2010/2011 - 2013/2014 academic session.

Data in table 12 shows an $\mathrm{R}$ value of 0.962 which implies that there is almost a Perfect Pearson's Products Moment Correlation Coefficient between the male students in Mock Senior School Certificate Examination and their scores in WASSCE between 2010/2011-2013/2014 session. It also shows an $\mathrm{R}$ square of 0.926 which is the Coefficient of Determination, this implies that $92.6 \%$ of the WAECSSCE Agricultural science is explained or accounted for by the Mock Senior School Certificate Examination. The shows that the regression equation for the male scores appear to be very useful for making prediction since the $R^{2}$ value of 0.962 is close to 1 .

Data in table 13 Shows an F-value of 25701.793 and $p$-value of 0.000 , since the $p$ value of 0.000 is less than 0.05 , we shall reject the null hypothesis which implies that 
students scores in Mock Senior School Certificate Examination Agricultural science do not significantly predict their scores in WASSCE Agricultural Science between 2010/2011-2013/2014 academic sessions. Therefore we accept the Alternate hypothesis which states that male students scores in Mock Senior School Examination significantly predicts their scores in WASSCE Agricultural science between 2010/2011-2013/2014 academic sessions.

Regression or Prediction Equation $=$ WAEC $=-7.32+1.136$ Mock Examination.

Data in table 14 establishes the prediction or regression equation as the unstandardized coefficient values of $B$ are -7.32 and 1.136 for the slope and the intercept respectively. Therefore the prediction equation for male scores is WASSCE $=-7.32+1.136$ Mock Examination. It also reveals that at 0.05 level of significance with a p-value of 0.000 which is less than 0.05, this implies that male student scores in Mock Senior School Certificate Examination Agricultural science significantly predict scores in WASSCE Agricultural Science between 2010/2011 2013/2014 academic sessions.

Data in table 15 show an $R$ value of 0.776 which implies that there is a Pearson's Products Moment Correlation Coefficient between the Mock Senior School Certificate Examination scores of student in schools located in Rural areas and their scores in WASSCE between 2010/2011-2013/2014 academic sessions. It also shows an $\mathrm{R}$ square of 0.602 which is the Coefficient of Determination which implies that $60.2 \%$ of the WASSCE Agricultural science is explained or accounted for by the Mock Senior School Certificate Examination. The shows that the regression equation for the scores of student in schools located in Rural areas appear to be very useful for making prediction since the $\mathrm{R}^{2}$ value of 0.602 .
Data in table 16 show an F-value of 2899.369 and p-value of 0.000 , since the pvalue of 0.000 is less than 0.05 , we shall reject the null hypothesis which states that MOCK SSCE scores in Agricultural Science of students located in Rural areas do not significantly predict their scores in WASSCE Agricultural science between 2010/2011-2013/2014 academic sessions. Therefore we accept the Alternate hypothesis which states that Mock Senior School Certificate Examination scores in Agricultural Science of students located in Rural areas significantly predict their scores in WASSCE Agricultural science between 2010/2011-2013/2014 academic sessions.

Regression or Prediction Equation WAEC = $1.189+0.788$ Mock Examination

Data in table 17 establishes the prediction or regression equation as the unstandardized coefficient values of B are 1.189 and .788 for the slope and the intercept respectively. Therefore the prediction equation for the scores of students located in Rural Area is WASSCE $=1.189+.788$ Mock Examination. It also reveals that at 0.05 level of significance with a p-value of 0.000 which is less than 0.05. This implies that Mock Senior School Certificate Examination scores in Agricultural Science of students located in Rural areas significantly predict their scores in WASSCE Agricultural science between 2010/2011-2013/2014 academic sessions

Data in table 18 Show an $\mathrm{R}$ value of 0.587 which implies that there is a Pearson's Products Moment Correlation Coefficient between the Mock Senior School Certificate Examination scores of student in schools located in Urban areas and their scores in WASSCE between 2010/2011-2013/2014 session. It also shows an $\mathrm{R}$ square of 0.344 which is the Coefficient of Determination 
which implies that $34.4 \%$ of the WASSCE Agricultural science is explained or accounted for by the Mock Senior School Certificate Examination. The shows that the regression equation for the scores of student in schools located in Urban areas appear to be very useful for making prediction since the $R^{2}$ value of 0.587

Data in table 19 Show an F-value of 1189.256 and $p$-value of 0.000 , since the $p$ value of 0.000 is less than 0.05 , we shall reject the null hypothesis which states that Mock Senior School Certificate Examination scores in Agricultural Science of students located in Urban Areas does not significantly predict their scores in WASSCE Agricultural science between 2010/2011-2013/2014 academic session. Therefore we accept the Alternate hypothesis which states that MOCK SSCE scores in Agricultural Science of students located in Urban areas significantly predict their scores in WASSCE Agricultural science between 2010/2011-2013/2014 academic sessions.

Regression or prediction Equation: WAEC $=$ $1.928+0.655$ Mock Examination

Data in table 20 establishes the prediction equation, as the unstandardized coefficient values of $\mathrm{B}$ are 1.928 and 0.655 for the slope and intercept respectively.

The findings from the analysed research question one shows that there was a moderate positive correlation which was significant between the student scores in Mock Senior School Certificate Examination and Student Scores in External Senior School Certificate Examination in Agricultural Science. It was indicated that there was a moderate positive correlation which was significant between the student scores in Mock-Senior School Certificate
Examination and WASSCE Agricultural Science between 2010/2011-2013/2014 academic session, while it was also indicated that there was a moderate positive correlation which was significant between the student scores in Mock Senior School Certificate Examination and the National Examination Council Examination between 2010/2011-2013/2014 academic sessions. This finding is in agreement with the findings of Nlebem (2011) who found out that there is a significant relationship between Mock Senior School Examination scores and the Senior School Certificate Examination score in Biology. The reason for the moderate positive correlation is not far fetched since the Mock Senior School examination is conducted to prepare candidates for the Senior School Certificate Examination. Corroborating this Okoye (2006) asserts that the Mock Senior School Certificate Examination is a pre-requisite examination which prepares candidates for final school examination which is the External Senior School Certificate Examination. The practical implication of this is that, a student who performs well in Mock Senior School Certificate Examination should also perform well in the WASSCE.

The findings from the analyses of research question two also show that there was a very high positive correlation which was significant between male students' scores in Mock Senior School Certificate Examination and WASSCE. This is in agreement with the findings of Okoye (2006) and Nlebem (2011) who in separate occasions revealed that there was significant relationship between the male student score in Mock-Senior School Certificate Examination and External Senior School Certificate Examination. 
Int.J.Curr.Res.Aca.Rev.2016; 4(2): 217-236

Table.1 Spearman Rank Order Correlation Coefficient between Students' Scores in MockSenior School Certificate Examination and Scores in West African Senior School Certificate Examinations (Wassce) Agricultural Science between 2010/2011 - 2013/2014 Academic Sessions

\begin{tabular}{lll}
\hline $\begin{array}{l}\text { Independent variable } \\
\text { MOCK }\end{array}$ & $\begin{array}{l}\text { Independent variable } \\
\text { MOCK }\end{array}$ & $\begin{array}{l}\text { Dependent variable } \\
\text { WAEC }\end{array}$ \\
\hline & 1.00 & $0.696^{* *}$ \\
& & 0.000 \\
$\mathrm{~N}$ & 3907 & 3.907 \\
Dependent Variable & $0.696^{* *}$ & 1.000 \\
WAEC & 0.000 & \\
$\mathrm{~N}$ & 3907 & 3,907 \\
** Correlation is significant at 0.01 level (2-tailed) $\mathrm{p}<0.05$
\end{tabular}

Table.2 Spearman Rank Order Correlation Coefficient between Mock- Senior School Certificate Examination Scores of Male Students and their Wassce Scores of in Agricultural Science between 2010/2011 - 2013/2014 Academic Sessions

\begin{tabular}{llll}
\hline & & MOCK & WAEC \\
\hline Spearman's rho & Mock Correlation coefficient & 1.000 & $.971^{* *}$ \\
& Sig (2-tailed) & & .000 \\
N & 2050 & 2050 \\
WAEC Correlation coefficient & $.971^{* *}$ & 1.000 \\
Sig (2-tailed) & .000 & \\
N & 2050 & 2050 \\
NECO Correlation coefficient & $.964^{* *}$ & $.986^{* *}$ \\
Sig (2-tailed) & .000 & .000 \\
& & \\
N & 2050 & 2050 & 2050 \\
\hline
\end{tabular}

Table.3 Spearman Rank Order Correlation Coefficient of Female Students' Scores in Mock Senior School Certificate Examination and their Wassce (Ssce) Scores in Agricultural Science between 2010/2011 - 2013/2014 Academic Sessions

\begin{tabular}{llll}
\hline & MOCK & WAEC \\
\hline Spearman's rho & Mock Correlation coefficient & 1.000 & $.991^{* *}$ \\
& Sig (2-tailed) & & .000 \\
N & 1857 & 1857 \\
WAEC Correlation coefficient & $.991^{* *}$ & 1.000 \\
Sig (2-tailed) & .000 & \\
N & 1857 & 1857 \\
Mock Correlation coefficient & $.970^{* *}$ & $.972^{* *}$ \\
Sig (2-tailed) & .000 & .000 \\
$\mathrm{~N}$ & 1857 & 1857 \\
\hline ** Correlation is significant at the 0.01 level (2-tailed). p $<0.05$ & &
\end{tabular}


Table.4 Spearman Rank Order Correlation Coefficient of the Students' Scores in Mock Senior School Certificate Examination Located in Rural Areas and their Scores in Wassce (Ssce) in Agricultural Science between 2010/2011 - 2013/2014 Academic Sessions

\begin{tabular}{llll}
\hline & & MOCK & WAEC \\
\hline Spearman's rho & Mock Correlation coefficient & 1.000 & $.792^{* *}$ \\
& Sig (2-tailed) & & .000 \\
N & 1641 & 1641 \\
WAEC & Correlation & $.792^{* *}$ & 1.000 \\
& coefficient & & \\
Sig (2-tailed) & .000 & \\
N & 1641 & 1641 \\
Mock Correlation coefficient & .781 & .751 \\
Sig (2-tailed) & .000 & .000 \\
N & 1641 & 1641 \\
** Correlation is significant at the 0.01 level (2-tailed) p<0.05 & &
\end{tabular}

Table.5 Spearman Rank Order Correlation Coefficient of the Students' Scores in Mock Examination of Schools Located in Urban Areas and their Scores in Wassce (Ssce) Agricultural Science Between 2010/2011 - 2013/2014 Academic Sessions

\begin{tabular}{llll}
\hline & MOCK & WAEC \\
\hline Spearman's rho & Mock Correlation coefficient & 1.000 & $.640^{* *}$ \\
& Sig (2-tailed) & & .000 \\
N & 2266 & 2266 \\
WAEC Correlation coefficient & $.640^{* *}$ & 1.000 \\
Sig (2-tailed) & 0.000 & \\
N & 2266 & 2266 \\
NECO Correlation coefficient & $.640 * *$ & $.667 * *$ \\
Sig (2-tailed) & .000 & .000 \\
$\mathrm{~N}$ & 2266 & 2266 \\
\hline ** Correlation is significant at the 0.01 level (2-tailed). p $<0.05$ & &
\end{tabular}

Table.6 Regression Analysis of Students' Scores in Mock-Senior School Certificate Examination Agricultural Science in Predicting their Scores in West African Senior School Certificate Examination Agricultural Science Between 2010/2011 - 2013/2014 Academic Sessions

\begin{tabular}{lllll}
\hline Model & R & R Square & Adjusted Rsquare & Standard error of the Estimate \\
\hline 1 & .651 & .424 & .424 & 1.433 \\
\hline a. Predictors: (constant), Mock & & &
\end{tabular}


Table.7 Summary of Regression in Anova Establishing if the Student Scores in Mock Senior School Certificate Examination in Agricultural Science Significantly Predicts their Scores in West African Senior School Certificate Examination (Wassce) in Agricultural Science Between 2010/2011 - 2013/2014 Academic Sessions

\begin{tabular}{llllll}
\hline Model & Sum of squares & Df & Mean square & F & Sig. \\
\hline Regression & 5901.212 & 1 & 5901.212 & 2875.071 & $0.000 \mathrm{~b}$ \\
Residual & 8015.189 & 3905 & 2.053 & & \\
Total & 13916 & 3906 & 3906 & & \\
\hline
\end{tabular}

Dependent Variable: WAEC

Predictors (Constant), Mock

Table.8 Summary of the Coefficient Value of the Students' Scores in Mock-Senior School Certificate Examination in Predicting their Scores in West African Senior School Certificate Examination Agricultural Science between 2010/2011 - 2013/2014 Academic Sessions

\begin{tabular}{llllll}
\hline \multicolumn{5}{l}{ Unstandardised coefficient } & \multicolumn{2}{l}{ Sig. } \\
\hline Model & B & Standard error & $\begin{array}{l}\text { Standard } \\
\text { Coefficients Beta }\end{array}$ & t & \\
\hline (Constant) & 1.642 & 0.077 & .651 & 21.372 & .000 \\
Mock & .706 & 0.013 & & 53.620 & .00 \\
\hline
\end{tabular}

Dependent Variable: WAEC. The regression or prediction Equation WASSCE $=1.642+0.706$ Mock Examination

Table.9 Summary of Regression Analysis of Female Student Scores in Mock Senior School Certificate Examination Agricultural Science Predicting their Scores in West African Senior School Certificate Examination(Wassce) Agricultural Science between 2010/2011 - 2013/2014 Academic Sessions

\begin{tabular}{lllll}
\hline Model & R & R Square & Adjusted Rsquare & Standard error of the Estimate \\
\hline 1 & $.989^{\mathrm{a}}$ & .978 & .978 & .27008 \\
\hline Predictors: Constant), Mock & & &
\end{tabular}

Table.10 Summary of Regression in Anova Showing the Prediction of Female Students' Scores in West African Senior School Certificate Examination(Wassce) by their Scores in Mock Senior School Certificate Examination Agricultural Science Between 2010/2011 - 2013/2014 Academic Sessions

\begin{tabular}{llllll}
\hline Model & Sum of squares & Df & Mean square & F & Sig. \\
\hline Regression & 6094.750 & 1 & 6094.750 & 83557.405 & $.000^{\mathrm{b}}$ \\
Residual & 135.305 & 1855 & .073 & & \\
\hline Dependent Variable: & & & &
\end{tabular}

Dependent Variable: WAEC

Predictors (Constant), Mock

Table.11 Summary of Coefficient Values of the Female Students' Scores in Mock Senior School Certificate Examination Agricultural Science Predicting their Scores in West African Senior School Certificate Examination Agricultural Science Between 2010/2011-2013/2014 Academic Sessions

\begin{tabular}{|c|c|c|c|c|c|}
\hline Model & B & $\begin{array}{l}\text { Un-standard } \\
\text { coefficient } \\
\text { Standard error }\end{array}$ & $\begin{array}{l}\text { Standard } \\
\text { Coefficients Beta }\end{array}$ & $\mathbf{T}$ & Sig. \\
\hline (Constant) & .048 & 0.019 & & 2.513 & 0.012 \\
\hline Mock & .982 & 0.003 & .989 & 289.063 & 0.000 \\
\hline
\end{tabular}


Int.J.Curr.Res.Aca.Rev.2016; 4(2): 217-236

Table.12 Summary of Regression Analysis of Male Students' Scores in Mock Senior School Certificate Examination Agricultural Science Predicting yheir Scores in West African Senior School Certificate Examination (Wassce) Agricultural Science between 2010/2011 - 2013/2014 Academic Sessions

\begin{tabular}{lllll}
\hline Model & R & R Square & Adjusted Rsquare & Standard error of the Estimate \\
\hline 1 & .962 & .926 & .926 & .51345 \\
\hline
\end{tabular}

Predictors: (Constant) Mock

Table.13 Summary of Regression in Anova Showing the Prediction of Male Students' Scores in West African Senior School Certificate Examination (Wassce) on Agricultural Science by the Mock Senior School Certificate Examination between 2010/2011 - 2013/2014 Academic Sessions

\begin{tabular}{llllll}
\hline Model & Sum of squares & Df & Mean square & F & Sig. \\
\hline Regression & 6775.786 & 1 & 6775.786 & 25701.793 & .000 \\
Residual & 539.916 & 2048 & .264 & & \\
Total & 7315.702 & 2049 & & & \\
\hline
\end{tabular}

Dependent Variable: WAEC

Predictors (Constant), Mock

Table.14 Summary of Coefficient Values of Male Students' Scores in Mock-Senior School Certificate Examination Predicting their Scores in West African Senior School Certificate Examination (Wassce) between 2010/2011 - 2013/2014 Academic Sessions

\begin{tabular}{llllll}
\hline Model & B & $\begin{array}{l}\text { Unstandardised } \\
\text { coefficient } \\
\text { Standard error }\end{array}$ & $\begin{array}{l}\text { Standardised } \\
\text { Coefficients } \\
\text { Beta }\end{array}$ & T & Sig. \\
\hline (Constant) & -7.32 & 0.043 & & -17.45 & .000 \\
Mock & 1.136 & 0.007 & .962 & 160.318 & .000 \\
\hline
\end{tabular}

Dependent Variable: WAEC

Table.15 Summary of Regression Analysis of Scores Students' in Schools Located in Rural Areas in Mock Senior School Certificate Examination Agricultural Science Predicting their Scores in West African Senior School Certificate Examination(Wassce) Agricultural Science between 2010/2011 - 2013/2014 Academic Sessions

\begin{tabular}{lllll}
\hline Model & R & R Square & Adjusted Rsquare & Standard error of the Estimate \\
\hline 1 & .776 & .602 & .602 & 1.08058 \\
\hline
\end{tabular}

Predictors (constant), Mock 
Table.16 Summary of Regression in Anova Showing The Prediction Of West African Senior School Certificate Examination Scores Of Students' In Schools Located In Rural Areas By Their Scores In Mock Senior School Certificate Agricultural Science Examination Between 2010/2011 -2013/2014 Academic Sessions

\begin{tabular}{llllll}
\hline Model & Sum of squares & Df & Mean square & F & Sig. \\
\hline Regression & 2899.369 & 1 & 2899.369 & 2485.079 & 0.000 \\
Residual & 1913.779 & 1639 & 1.168 & & \\
Total & 4813.148 & 1640 & & & \\
\hline
\end{tabular}

Dependent Variable: WAEC

Predictors (Constant), Mock

Table.17 Summary of Coefficient Values of the Mock Senior School Certificate Examination Scores of Students' in Schools Located in Rural Areas Predicting their Scores in West African Senior School Certificate Examination(Wassce) Agricultural Science Between 2010/2011- 2013 /2014 Academic Sessions

\begin{tabular}{llllll}
\hline Model & $\begin{array}{l}\text { Un-standard coefficient } \\
\text { B }\end{array}$ & $\begin{array}{l}\text { Standard } \\
\text { error }\end{array}$ & $\begin{array}{l}\text { Standard } \\
\text { Coefficients Beta }\end{array}$ & T & Sig. \\
\hline (Constant) & 1.189 & .092 & & 12.983 & \\
Mock & .788 & .016 & .776 & 49.831 & \\
\hline
\end{tabular}

Dependent Variable: WAEC

Table.18 Summary of Regression Analysis of Student Scores in Schools Located in Urban Areas in Mock Senior School Certificate Examination Agricultural Science Predicting their Scores in West African Senior School Certificate Examination (Wassce) Agricultural Science between 2010/2011 - 2013/2014 Academic Sessions

\begin{tabular}{lllll}
\hline Model & R & R Square & Adjusted Rsquare & Standard error of the Estimate \\
\hline 1 & .587 & .344 & .344 & 1.63201 \\
\hline Predictors (const) & & &
\end{tabular}

Table.19 Summary of Regression in Anova Showing the Prediction of Students' Scores in West African Senior School Certificate Examination of Students Located in Urban Areas by their Scores in Mock Senior School Certificate Examination Agricultural Science between 2010/2011 -2013/2014 Academic Session

\begin{tabular}{llllll}
\hline Model & Sum of squares & Df & Mean square & F & Sig. \\
\hline Regression & 3167.519 & 1 & 3167.519 & & .000 \\
Residual & 6030.041 & 2264 & 2.663 & 1189.256 & \\
Total & 9197.559 & 2265 & & & \\
\hline
\end{tabular}

Dependent Variable: WAEC; Predictors (constant) MOCK

Table.20 Summary of Coefficient Values of the Urban Students' Scores in Mock Senior School Certificate Examination Predicting their Scores in West African Senior School Certificate Examination(Wassce) Agricultural Science between 2010/2011 - 2013 /2014 Academic Sessions

\begin{tabular}{llllll}
\hline Model & $\begin{array}{l}\text { Un-standard coefficient } \\
\text { B }\end{array}$ & $\begin{array}{l}\text { Standard } \\
\text { error }\end{array}$ & $\begin{array}{l}\text { Standard } \\
\text { Coefficients Beta }\end{array}$ & $\mathbf{t}$ & Sig. \\
\hline (Constant) & 1.928 & .112 & & 17.237 & .000 \\
Mock & .655 & .019 & .587 & 34.486 & .000 \\
\hline
\end{tabular}

Dependent Variable: WAEC 
The finding from the analysed research question three shows that there was a very high positive correlation which was significant between the female student scores in Mock Senior School Certificate Examination and their scores in External Senior School Certificate Examination Agricultural Science conducted by West Africa Certificate Examination between 2010/2011-2013/2014 academic session. This is in agreement with the findings of Nlebem (2011) who found out that there is a significant relationship between females score in Mock Senior School Certificate Examination and WASSCE. Similarly Adesoji and Kenni (2013) also find out that female students score in Mock Senior School Certificate Examination significantly correlated with their WASSCE.

The findings from the analyses of research question four show that there was a high positive correlation which was significant between the Mock Senior School Certificate Examination scores of students in schools located in rural area and their score in Senior School Certificate Examination Agricultural Science conducted by West African Certificate Examination (WAEC) between 2010/2011- 2013/2014 academic session. This is in agreement with the findings of Nlebem (2011) who found out there was a significant relationship between Mock Senior School Certificate Examination scores and WASSCE score of students in rural school location. The practical implication of this finding is that students from schools located in Rural Areas are doing favourably well in academics and should not be neglected.

The findings from research question five also show that there was a moderate positive correlation which was significant between Mock Senior School Certificate Examination scores of students in schools located in Urban areas and their scores in WASSCE Agricultural Science conducted by West African Certificate Examination between 2010/2011- 2013/2014 academic session. This is in agreement with the findings of Nlebem (2011) who revealed there was a significant relationship between Mock Senior School Certificate Examination scores and WASSCE score of students in Urban school location. The practical implication of this finding is that students from schools located in Urban Areas are doing well as excepted since most of them are in good public schools that are well equipped with adequate infrastructure and good teachers that will aid their academic success

The findings are in agreement with Adesoji \& Kenni (2013) who found that Mock Examination results could be used to predict performance of Students in the Senior School Certificate Examination, hence the practical implication of this finding is that it has been established that the student scores in Mock Senior School Certificate Examination can be used to predict students score in the WASSCE.

The findings is in agreement with the findings of Adesoji \& Kenni (2013), who found out that male students performance in Mock Senior School Certificate Examination predicted their performance in West African Senior School Certificate Examination. Hence the practical implication of these findings are that it has been establish that the male student scores in Mock Senior School Certificate Examination can be used to predict students score in the External Senior School Certificate Examination conducted by WAEC and it is influenced by gender as it predicted the scores of both female and male students. The findings is in agreement with the findings of Adesoji and Kenni (2013) 
that male students performance in Mock Senior School Certificate Examination predicted their performance in West African Senior School Certificate Examination. Similarly Nlebem (2011) found out that the prediction of the External Senior School Certificate Examination by the Mock Senior School Certificate Examination has nothing to do with gender in Biology.

The findings are in agreement with the findings of Nlebem (2011) who reported that there was a significant relationship between the Mock Senior School Certificate Examination score and Senior School Certificate Examination in Biology of students Located in Urban areas. The practical implication of these findings include that Urban schools do possess very good academic qualities which enhance their academic performance It could also be that since the study was carried out in Government owned school, it can be that the teachers in Urban schools are committed to their teaching profession.

\section{Conclusion}

There was a positive correlation which was significant between the students' MockSenior School Certificate Examination scores and their scores in the External Senior School Certificate Examination Agricultural Science conducted by the West African Examination Council between 2010/2011-2013/2014 academic sessions. The correlation between the students' Mock Senior School Certificate Examination scores and their Scores in the External Senior School Certificate Examination Agricultural Science conducted by the West African Examination Council based on gender and school location between 2010/2011-2013/2014 academic sessions was positive and significant.The students' scores in Mock Senior School
Certificate Examination was a good predictor of their scores in External Senior School Certificate Examination in Agricultural Science conducted by the West African Examination Council between 2010/2011-2013/2014 academic sessions. The students' scores in Mock Senior School Certificate Examination was a good predictor of their scores in External Senior School Certificate Examination Agricultural Science conducted by the West African Examination Council based on gender and their school location between 2010/2011-2013/2014 academic sessions.

Finally, the Mock Senior School Certificate Examination becomes a very good assessment tool for preparing students for External Senior School Certificate Examination conducted by both the West African Examination Council.

\section{References}

Abia State Ministry of education (2013). Statistic of education. Umuahia, Department of planning, research and statistics.

Abia State Secondary Education Management Board (2014). Statistic of education. Umuahia, Department of planning, research and statistics.

Adesoji, F.A.\& Kenni, A.M. (2013). Continuous assessment, mock results and gender as predictors of academic performance of chemistry students in WASSCE and NECO examinations in Ekiti stat: Journal of international educational studies. Vol. 6(7), $1-8$.

Adeyegbe, S.O. (2004). Research into STM curriculum and school examination in Nigeria.The state of the proceedings of the STAN annual conference.

Emmanuel, E.A., Peter, O.A. \& Christopher, .O.(2011). Some Nigerian student's performance in practical an theoretical chemistry tests as predictors of their performance in MOCK-SSCE chemistry 
Int.J.Curr.Res.Aca.Rev.2016; 4(2): 217-236

examination. Journal of Science researches.3(12), 30-37

Erebor, O. (2003).Compressive agricultural science for senior secondary schools. Benin.:A Johnson Publisher Ltd.

Federal Republic of Nigeria (2004).National policy on education, Lagos: NERDC, press.

Federal Republic of Nigeria, (2013).National Policy on Education ( $4^{\text {th }}$ ed.). NERDC, press

Food \& Agricultural Organization (2006). Addressing the global food crises, key trade investment and commodity policies ensuring sustainable food security and alleviating poverty.

Joshua, S.D. (2007). Attitudinal disposition of seminar secondary school students towards agriculture in Maiduguri metropolitan Borno State. Medwell Agricultural journal. 3(2): $120-124$.

Maduabum, M.A. (2004). Fundamentals of education research. Owerri: Versatile Printers.

Nkemakolam, E. (2003). Taxanomy of educational measures. In B.G. Nworgu (Ed): Educational measurement and education: theory and practice. Revised edition Nsukka: University Trust publishers. $66-83$.

Nkemakolam, E.O (1995). Designing and conduction research in education. Owerri: CANUS Publishers Nigeria Limited.

Nkemakolam, E.O, Igbokwe U.O \& Mkpa, N.D (1997). Statistics in Education, Fundamental Concepts and Procedure. Owerri: CANUS Publishers Nigeria Limited.

Nkemakolam, E.O. (2000). Measurement in Education: An Introduction. Owerri: Barloz Publishers Limited.
Nkemakolam, E.O. (2009). Measurement in Education: An introduction: Enugu Jibaco Publishers.

Nlebem, F.J. (2011). Predictive validity of mock SSCE scores on senior school certificate of biology in Umuahia education zone of Abia state. Unpublished M.Sc Thesis. Abia State university. Uturu.

Nwanna, O.C.(2007) Educational measurement for teachers. Lagos: Thomas Nelson and Sons Press.

Okoye, L. (2006)."Attitude and practices of senior school teacher", Unpublished M.Ed dissertation University of Nigeria, Nsukka.

Olatunji, S.O., Akanwa, U.N. \& Nwahunanya, C.I. (2004). Measurement and evaluation of learning outcomes. Lagos: Naphtali prints limited.

Olatunji, S.O.,Akanwa, U.N. and Nwahunnaya, C.I. (2004).Measurement and Evaluation of learning outcomes. Lagos: Naphtali prints: A division of HG Support Nigeria Limited.

Olorundare, A.S. (2014).Theory into practice: beyond surface curriculum in science. $147^{\text {th }}$ Inaugural lecture of the University of Ilorin, p 26. $22^{\text {nd }}$ May, 2014

Salau, M.O. (1999). Comparative effects of attending single sex and co-educational secondary schools on the female students achievement in mathematics. In: B. Olanitemi (ed). Proceeding of science teachers association of Nigeria, Ibadan: Heinemann Education Book.

Ukwuije, R.P.I. (2012). Educational assessment: A sine qua non for quality education. $83^{\text {rd }}$ inaugural lecture. University of Port Harcourt. Port Harcourt.

\section{How to cite this article:}

Madu, Aldophus and Ebere, Collins. 2016. Predictive validity of Mock senior School certificate examination on external wassce scores in agricultural science in Abia state, Nigeria.Int.J.Curr.Res.Aca.Rev. 2016.4(2): 217-236.

doi: http://dx.doi.org/10.20546/ijcrar.2016.402.027 